\title{
ABOUT THE INSTRUMENTATION OF BASS AND MELODY LINE IN LEOŠ JANÁČEK'S SINFONIETTA AND MLÁDÍ
}

Leoš Janáček's orchestral and chamber music works belong to the most significant compositions of the first half of the 20th century. Besides his numerous stage works Janáček created a series of orchestral works, such as Taras Bulba (1915-18), Balada Blanická (1919) and Sinfonietta (1926). Due to their expressiveness, complexity and numerous instrumentational refinements they belong to the most exciting orchestral works of the interwar period.

While a whole set of musicological treatises deal with formal, thematic and motivic aspects of his orchestral music, the finesses in instrumentation of his orchestral oeuvre remained largely unexplored. ${ }^{1}$

The aim of this paper is to look at the design of the bass and melody line in Janáček's Sinfonietta from a music-analytical perspective. The following aspects are presented in details: instrumentation of the bass line, octave doublings of the melody line within a movement, as well as the participation of the low strings and the brass section in the performance of the melody.

Sinfonietta's first world performance was in 26th of June 1926 in Prague, performed by the Czech Philharmonic conducted by Václav Talich. A few months later, Sinfonietta was performed again in Germany and the USA under Otto Klemperer. Since then, Sinfonietta belongs to the standard repertoire of the classical music of the 20th century.

The instrumentation of this orchestral work is unique. With twelve trumpets, two tenor tubas, four horns, four trombones and a tuba the group of the brass instruments surpasses the size of a typical big symphonic orchestra. An explanation for this unproportional participation of the brass instruments is the original

1 Noteworthy exceptions are among others: MAEHDER, Jürgen. Klangfarbe und Orchestertechnik im Spätwerk Leoš Janáčeks. In Leoš Janáček: Konzeption und Rezeption seines musikdramatischen Schaffens, (ed. Walter Bernhart). Anif / Salzburg: Verlag Müller-Speiser 1997, p. 67-85; MACKERRAS, Charles. Orchestration problems and the revised edition. In: Leoš Janáček: Káta Kabanová, (ed. John Tyrell). Cambridge: Cambridge University Press, 1982, p. 143-154. 
idea of the composer to compose the Sinfonietta as an open air Fanfare for brass instruments for the Czech sports club Sokol. ${ }^{2}$

Despite that, L. Janáček decided to compose it as a 25-minute orchestral work in five movements. Every movement has an individual instrumentation where a different group of instruments has a dominant character. On the fanfares of the brass (1st movement: Allegretto), follows the second movement with an Andante from the woodwinds. Strings dominate the third movement (Moderato) and in the fourth movement begins a "Polka-type motif" in the trumpet which is then orchestrated for the entire duration of the movement by other instruments. In the beginning of the finale the tone colors of the woodwinds and the brass are combined followed slowly by the rest of the instruments. A Tutti closes the entire composition.

In his musicological study about the late work of Leoš Janáček, Dieter Schnebel sketches the timbre characteristics of every movement of this orchestral piece. ${ }^{4}$ The tone colors of the Sinfonietta "unfold their own existence" and "have their own flow". "This "own flow" of the tone colors is explained by D. Schnebel through a harmonic and thematic-motivic analysis. ${ }^{7}$

The aim of this paper is to describe the flow of the tone colors of the diverse motifs of the Sinfonietta according to their orchestration.

In the second movement of the Sinfonietta appear four motifs which are repeated several times. Although these repeated motifs have the same thematic structure, they gain a different tone color through different orchestrations. On the one hand, through these discolorations, Janáček manages to avoid sound monotony, while on the other hand his music gains tone-color diversity.

Specific processes become apparent if the entire orchestration of a motif is considered from an overarching perspective. Fig. 1-6 and Ex. 1-4 demonstrate how L. Janáček compositionally controls the entire tone coloration of the second movement of his Sinfonietta.

The first motif of the second movement is played by two Clarinets in $\mathrm{Bb}$ (Ex. 1) in 32nd notes.

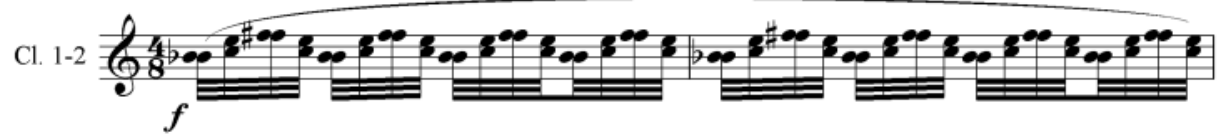

Ex. 1 Sinfonietta, II. movement: accompaniment-motif 1 (bar: 1).

2 See HONOLKA, Kurt. Leoš Janáček, Sein Leben, Sein Werk, Seine Zeit. Stuttgart: Belser Verlag, 1982, p. 242-251.

3 HONOLKA, op. cit., p. 245.

4 SCHNEBEL, Dieter. Das Späte Neue, Versuch über Janáčeks Werke 1918-1928. In Musik-Konzepte 7, Leoš Janáček (eds. Heinz-Klaus Metzger and Rainer Riehm). München: Johannesdruck Hans Pribil KG, 1979, p. 75-90.

5 Ibid., p. 75.

6 Ibid., p. 76.

7 Ibid., p. 77-80. 
Four bars later, a motif in 8th notes appears in the trombones and the bassoons, which is differently articulated than the 32nd notes motif (Ex. 1: legato / Ex. 2: staccato). This 8th note motif functions as an accompaniment for the next 25 bars.

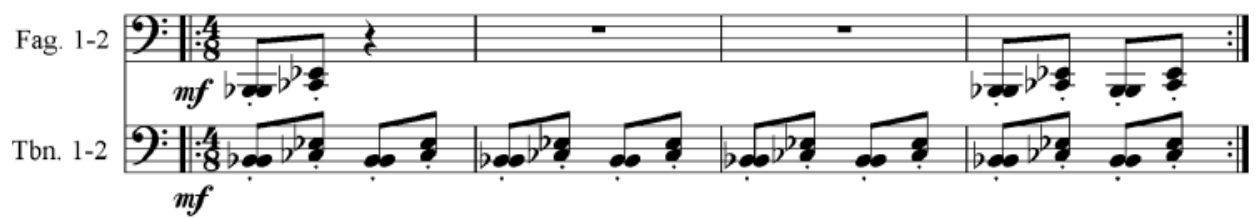

Ex. 2 Sinfonietta, II. movement: accompaniment-motif 2 (bar: 5).

Right after the 32nd note motif appears again and takes on the function of the accompaniment for the bars 31 to 60 .

The third motif (Piu Mosso-motif) if played for the first time by the low strings in bar 61 (Ex. 3). On the many repetitions of this motif, Janáček changes the total number of instrument combinations 17 times during the next 105 bars.

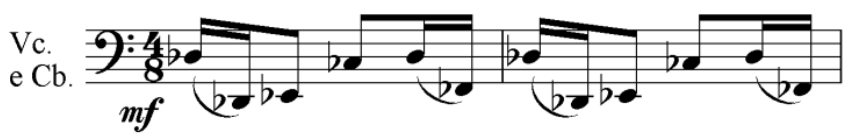

Ex. 3 Sinfonietta, II. movement: accompaniment-motif 2 (bar: 61).

In bar 166 the harp enters for the first time and plays the fourth accompaniment motif (Ex. 4 / Harp motif).

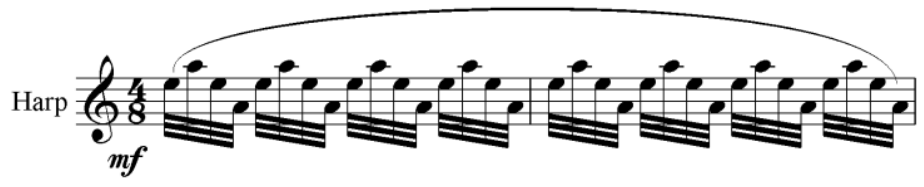

Ex. 4 Sinfonietta, II. movement: accompaniment-motif 2 (bar: 166).

The 32nd note motif appears again in bar 193 and thus ends the first movement.

Fig. 1 gives an overview of all four accompaniment motifs of the second movement of the Sinfonietta. The grey line indicates the entry of the according motif.

Each motif has a different combination of instruments. The domination of instruments on each motif is as follows: on the first one (32nd notes) the woodwinds and strings, on the second (8th notes) the woodwinds and brass, on the third (Piu Mosso) the strings and on the fourth (Harp) the strings and the harp. 
Sinfonietta, II. movement: Overview of all four accompaniment-motifs

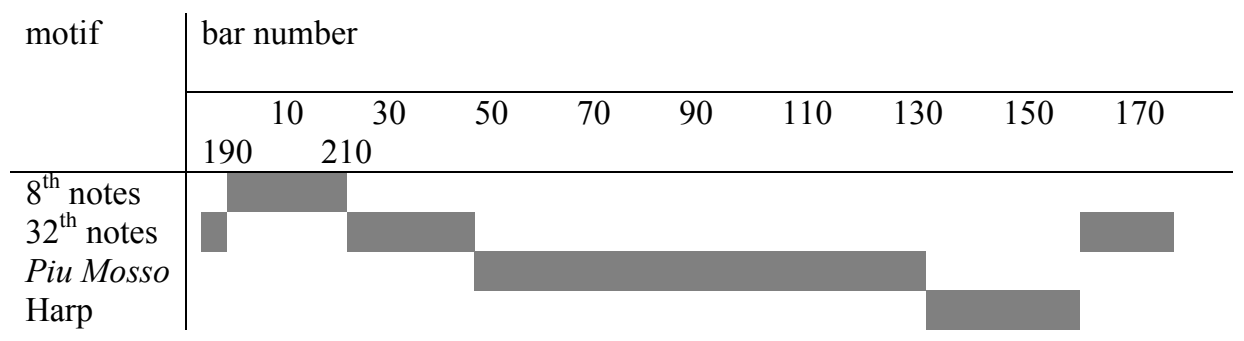

Fig. 1.

Every first appearance of the four accompaniment motifs has a different orchestration. The 8th note motif is played for the first time by the trombones and bassoons. This is a combination which up till now was never used in the second movement. The same applies for the two other motifs (Piu Mosso-Motif: low strings, bar 61/ fourth motif: Harp, bar 166).

L. Janáček goes a step further and not only does he organize the tone colors of these four motifs, but also uses specific criteria for the sequence of the different instrumental combinations.

The first accompaniment motif is repeated 19 times. Of these 19 tone color combinations, 7 are different. Some of them appear often, while others only once. Fig. 2 shows not only the exact listing of the used instruments (second row) and the bars in which they appear (third row), but also enumerates the tone color combinations occurring after their appearance (first row).

The first combination of instruments $(\mathrm{Cl}$. 1-2 / bar 1) appears again on bar 31 and exactly after the motif is played by the violins (2nd combination / bar 32). After the third combination (clarinets with violins, bar 37) the first one follows again (bar 38) and so on. The sequence of the chosen combinations is: $1^{\text {st }}, 1^{\text {st }}, 2^{\text {nd }}$,

\section{Sinfonietta, II. movement: accompaniment-motif 1 (thirty second-notes)} (first appearance: bar 1)

\begin{tabular}{l|l|l} 
combination & $\begin{array}{l}\text { instruments } \\
\text { of the combination }\end{array}$ & bar \\
\hline 1st & Cl.1-2 & $1,31,38$, \\
2nd & Vln.1 + Vln.2 & $32,40,47,52,56$ \\
3rd & Cl.1-2 + Vln.1 + Vln.2 & 37 \\
4th & Fl.1-2 + Vln.1 + Vln.2 & $39,45,50$ \\
5th & Fl.1-2 & $46,51,55,57$ \\
6th & Vla. (divisi) & 193,201 \\
7th & Vln.2 (div) + Vla. (divisi) & 194,203
\end{tabular}

Fig. 2 
$3^{\text {rd }}, 1^{\text {st }}, 4^{\text {th }}, 2^{\text {nd }}, 4^{\text {th }}, 5^{\text {th }}, 2^{\text {nd }}, 4^{\text {th }}, 5^{\text {th }}, 2^{\text {nd }}, 5^{\text {th }}, 2^{\text {nd }}, 5^{\text {th }}, 6^{\text {th }}, 7^{\text {th }}, 6^{\text {th }}$ and $7^{\text {th }}$. Fig. 2 shows a graphical representation of the sequence of all four motifs.

Ex. 5 lists the appearances of the first accompaniment motif. Due to space limitations, only the beginning of the bar is shown.
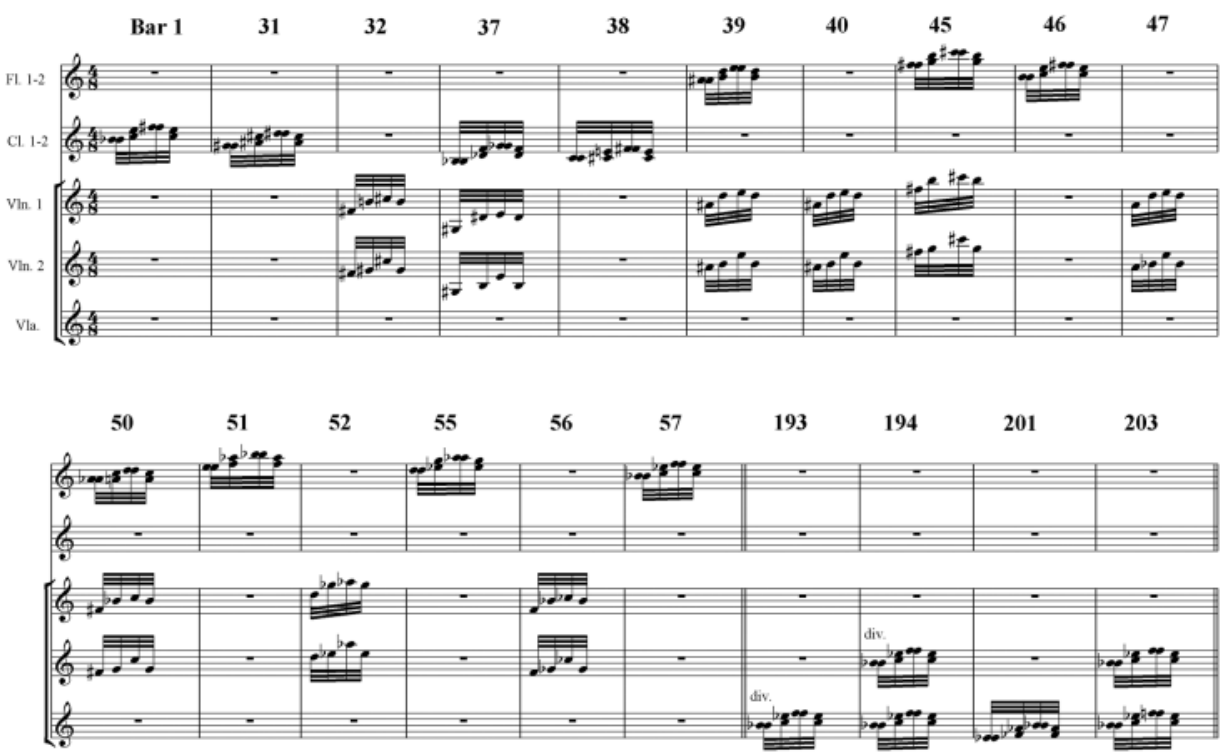

Ex. 5 Sinfonietta, II. movement: listing of all appearances of the accompaniment-motif 1.

The similar applies for the second (Fig. 3 and Ex. 6), the third (Fig. 4 and Ex. 7) and the fourth (Fig. 5 and Ex. 8) motif.

Sinfonietta, II. movement: accompaniment-motif 2 (eight-notes) (first appearance: bar 5)

\begin{tabular}{|c|c|c|}
\hline combination & $\begin{array}{l}\text { instruments } \\
\text { of the combination }\end{array}$ & bar \\
\hline 1 st & Fag. $1-2+$ Tbn.1-2 & $5 \mathrm{a}, 8,14,17$, \\
\hline 2nd & Tbn.1-2 & $5 b, 11,16$ \\
\hline $3 \mathrm{rd}$ & Fag. $1-2+$ Tbn.1-2 + Vc. + Cb. & $22 \mathrm{a}, 25,26 \mathrm{a}$ \\
\hline 4th & Tbn.1-2+ Vc. $+\mathrm{Cb}$ & $22 b, 26 b$ \\
\hline
\end{tabular}

Fig. 3 


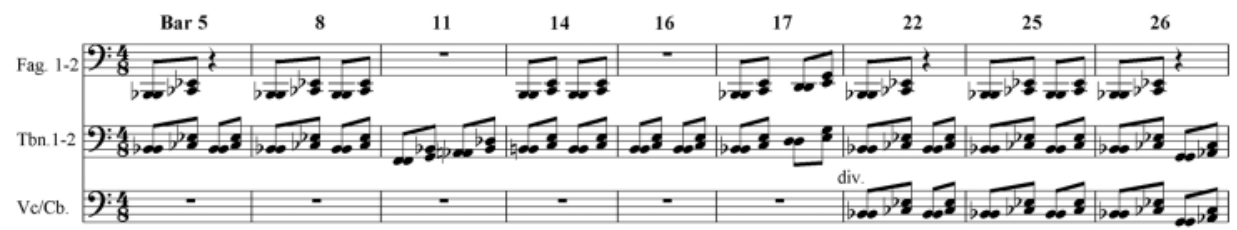

Ex. 6 Sinfonietta, II. movement: listing of all appearances of the accompaniment-motif 2.

\section{Sinfonietta, II. movement: accompaniment-motif 3 (Piu Mosso)}

(first appearance: bar 58)

\begin{tabular}{l|l|l} 
combination & $\begin{array}{l}\text { instruments } \\
\text { of the combination }\end{array}$ & bar \\
\hline 1st & Vc. + Cb & $61,123,148$ \\
2nd & Vla. & $98,120,126,153 \mathrm{a}$ \\
3rd & Vln.2 & $104,117,128$ \\
4 th & Vln.1 & 110,131, \\
5 th & Vln.1+Vla. & 135 \\
6th & Fl.1+Vla. & 141 \\
7th & Hn.2+Vla. & $153 \mathrm{~b}$ \\
8th & Hn.2+Vln.1+Vla & 154 \\
9th & Cl.1 + Vla. & 159
\end{tabular}

Fig. 4

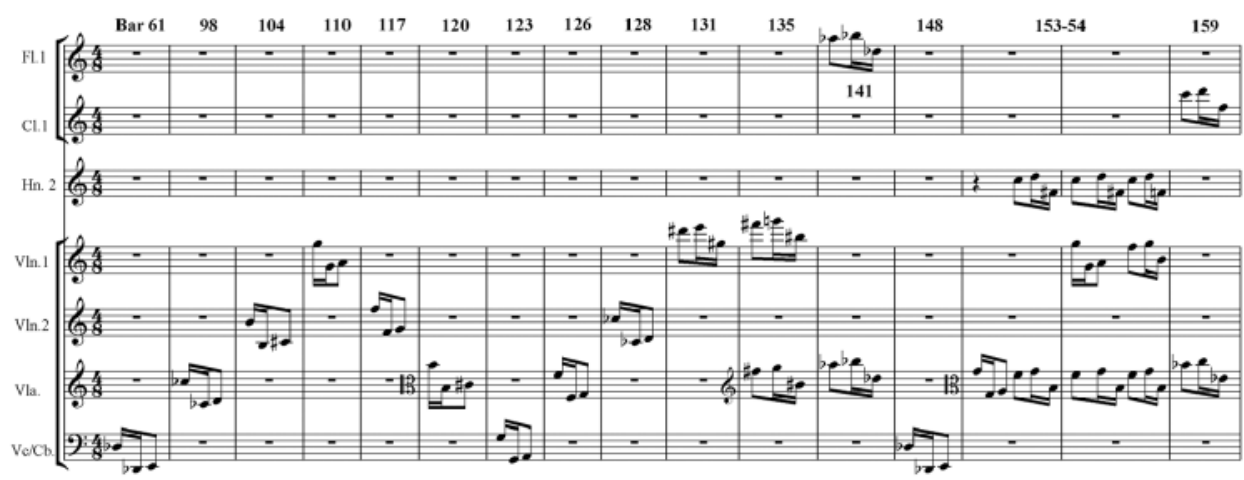

Ex. 7 Sinfonietta, II. movement: listing of all appearances of the accompaniment-motif 3. 
Sinfonietta, II. movement: accompaniment-motif 4 (Harp) (first appearance: bar 58)

\begin{tabular}{l|l|l} 
combination & $\begin{array}{l}\text { instruments } \\
\text { of the combination }\end{array}$ & bar \\
\hline 1st & Harp & $166,172,183$ \\
2nd & Harp + Vla. & 168,174 \\
3rd & Harp + Vln.1 + Vln.2 & 179,190 \\
4th & Vln.1 + Vln.2 & 193
\end{tabular}

Fig. 5

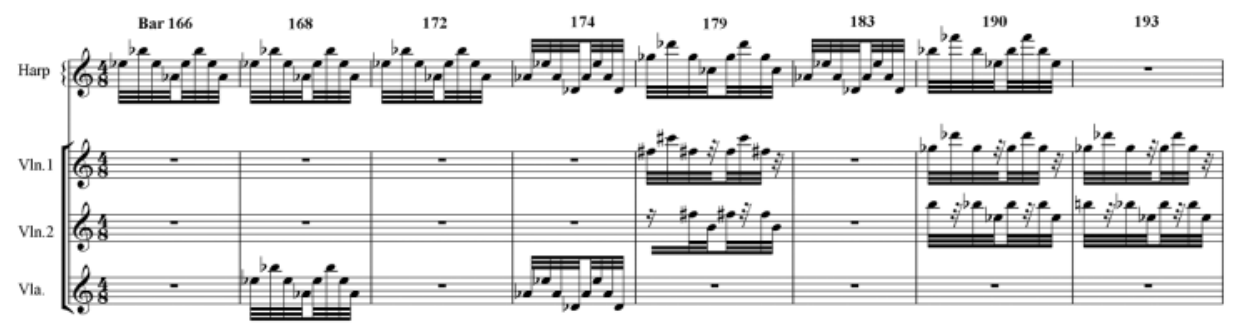

Ex. 8 Sinfonietta, II. movement: listing of all appearances of the accompaniment-motif 4.

Fig. 6 shows a graphical representation of the sequence of all four motifs. By closer examination of this table, we get the following results:

- Janáček tries to accomplish a variety of tone colors. Especially in the 32nd notes and the Piu Mosso-motifs the number of the different combinations is high.

- The following model applies for all four accompaniment motifs; in the few first times the motif appears, it does so with different instrumental combinations which are later repeated.

- There is often a change between new and already used combinations.

- The last appearance of a motif is usually a new one.

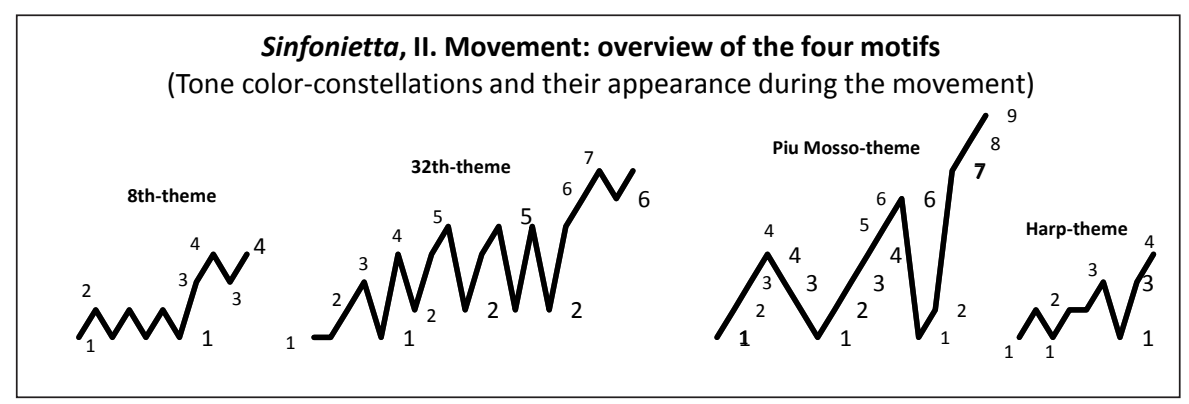

Fig. 6 
The string melody of bar 1 of the third movement of the Sinfonietta will be analyzed with the same criteria as the accompanying voices of the second movement. It turns out, that the melody line, which is always present during the movement, is orchestrated in the same refined way as the accompaniment motifs of the previous movement.

The main theme of the movement which is played by the violins in the very beginning (Ex. 9) is very often repeated in various doublings.

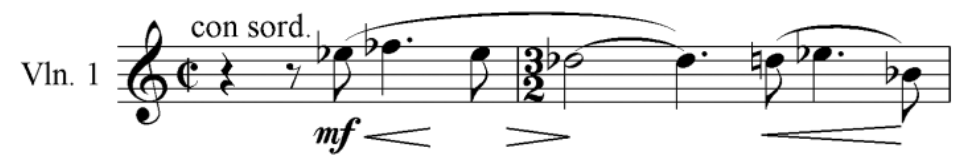

Ex. 9 Sinfonietta, III. movement: violin melody (bar: 1-2).

Ex. 10 describes the various doublings (bar 1) and the doubling at the octave (bar 2) of the main theme in the first two bars.

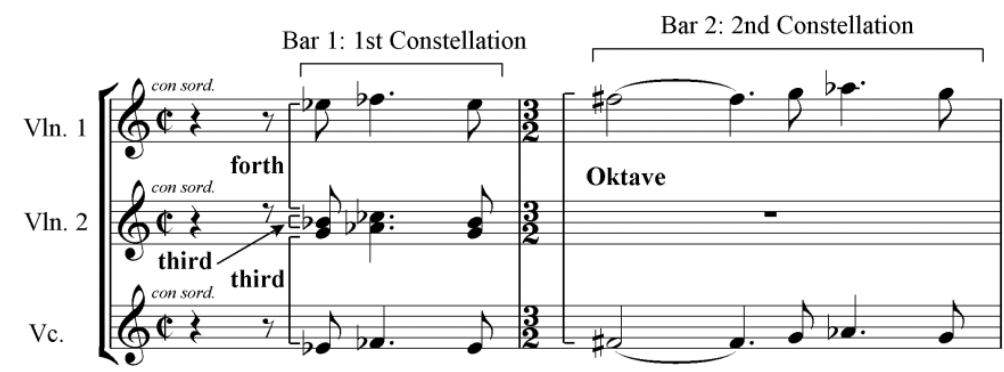

Ex. 10 Sinfonietta, III. movement: various doublings of the melody line (bar: 1-2).

Fig. 7 lists all tone color changes of this melody for the entire duration of the third movement

It appears that during the entire movement there exist 26 tone color changes of the main theme. Of these, 22 different from one another. The slightly different discolorations of this theme are the reason why, despite its many appearances, firstly: there is no sound monotony and secondly: the attention of the audience remains high during every repetition.

Ex. 11 gives an overview of all the appearances of the main theme and indicates the combinations which correlate with one another (bar 15 correlates with 173: Ob. 1-2 / bar 20 with bar 180: Cor. Ingl. / bar 26 with T. 99-100: Cl. b. / bar 79-80 with bar 89-90: Trb.1). 


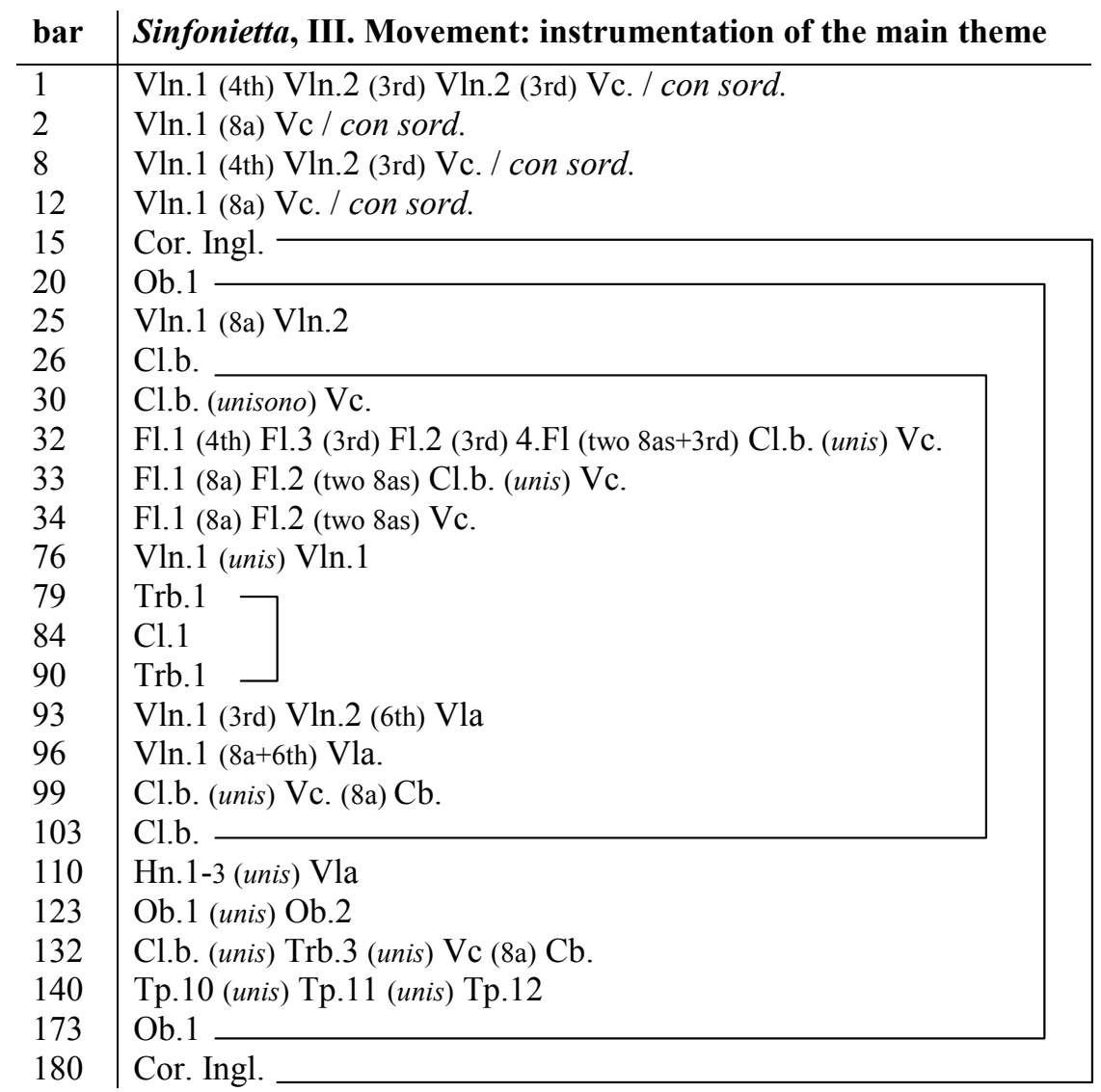

Fig. 7

The main theme of the fourth movement, which is strongly influenced by folklore, ${ }^{8}$ has strong similarities with the melody of the previous movement in relation to the discolorations of its repetitions. Fig. 8 lists all appearances of the main theme of the fourth movement. Like in the previous movement, Janáček avoids repetitions of the theme with identical instrumentation. Of the nine repetitions of the main theme, 8 are different (bar 1 correlates with bar 135: Tp. 1-3).

8 See HOLLANDER, Hans. The Music of Leoš Janáček, It's Origin in Folklore. The Musical Quarterly, 1955, vol. 41, no. 2 (April), p. 171-176. 


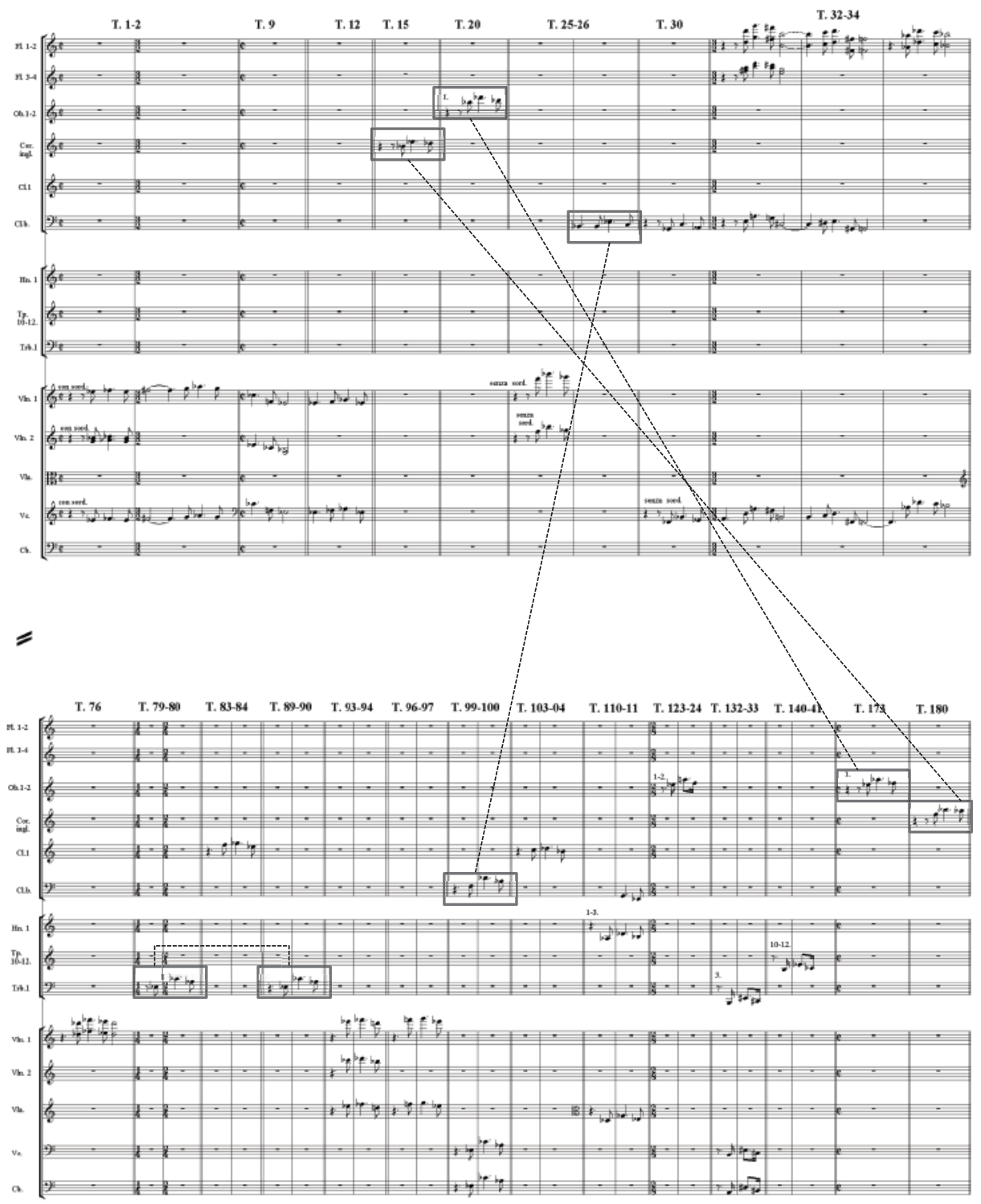

Ex. 11 Sinfonietta, III. movement: listing of all appearances of the main theme.

Ex. 12 gives an overview of all the appearances of the main theme.

A symphonic orchestra offers various possibilities of tone color changes in a melody. A chamber music ensemble, which consists of sic monophonic instruments, offers considerably fewer possibilities to change the tone color nuances of a melody. 


\begin{tabular}{l|l|} 
bar & $\begin{array}{l}\text { Sinfonietta, IV. movement: } \\
\text { instrumentation of the main theme }\end{array}$ \\
\hline & Tp.1-3. \\
1 & Ob.1-2 (8a) Hn.1-3 \\
41 & Cl.1-2 (Unisono) Vla. (8a) Hn.1-3 \\
54 & Hn.1 (8a) Hn.2 \\
69 & Fl.1 (8a) Fl.2 \\
78 & Vln.1 (8a) Vln.2 \\
85 & Vln.1 (3rd) Vln.2 (8a+5th) Vla. \\
135 & Tp.1-3 \\
151 & Ob.1-2
\end{tabular}

Fig. 8

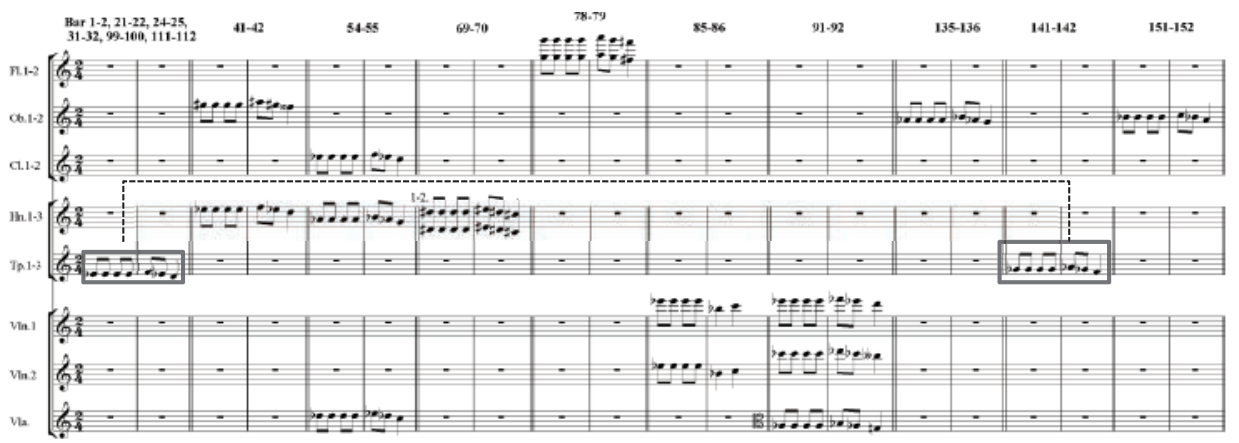

Ex. 12 Sinfonietta, IV. movement: listing of all appearances of the main theme.

The chamber music work Mládi belongs, like Sinfonietta, to the late work of Leoš Janáček. Both pieces were not only composed in a two year period, but also refer to the same geographical location. The Czech city Brno is the common connection of both compositions. Originally, all five movements of the Sinfonietta had titles which were directly connected to this city. Inspired by many happy memories of his youth in that city, Leoš Janáček composed at the age of 70 the wind sextet Mládí (Youth).

While there exists many analytical studies about his late chamber music work considering the aspects of form, harmony and motivic analysis of his music, ${ }^{9}$ there is a lack of analysis of the strategies of the instrumentation which Leoš Janáček uses in these works.

9 See KADERAVEK, Milan Robert. Stylistic Aspects of the Late Chamber Music of Leoš Janáček: an Analytic Study. Illinois: UMI Dissertation Services, 1971. 
The fourth movement of Mládi begins with an accompaniment motif which consists only by repeated notes. The persistence of this motif is remarkable. Constantly repeated notes accompany the melody line of this movement from bar 1 to bar 66. The way that the accompaniment motif of the fourth movement of Mládi is orchestrated in the first 66 bars is similar to the way the accompaniment motif of the second movement and the melody line of the third and fourth movement of the Sinfonietta is orchestrated.

Fig. 9 and Ex. 13 list all the tone color changes of the repetition motif for the bars 1 to 66 .

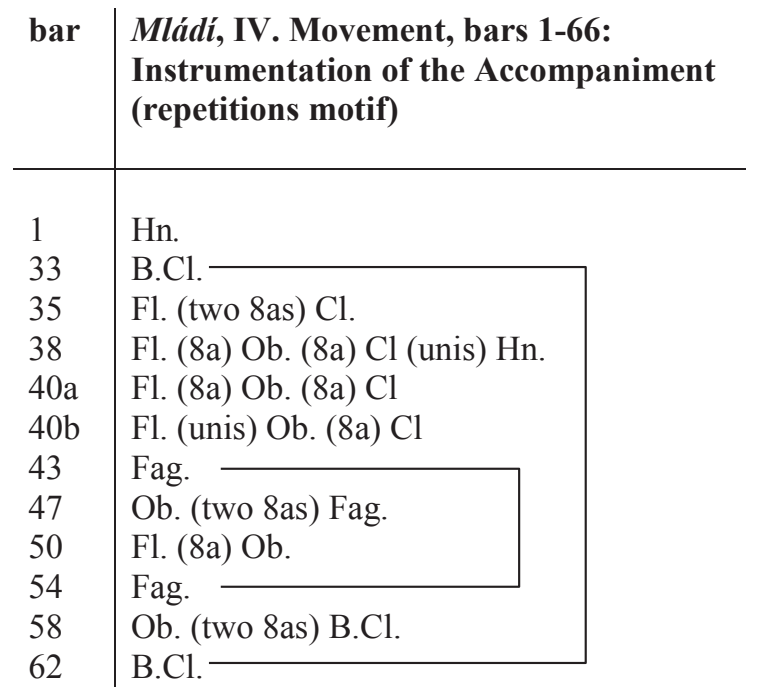

Fig. 9

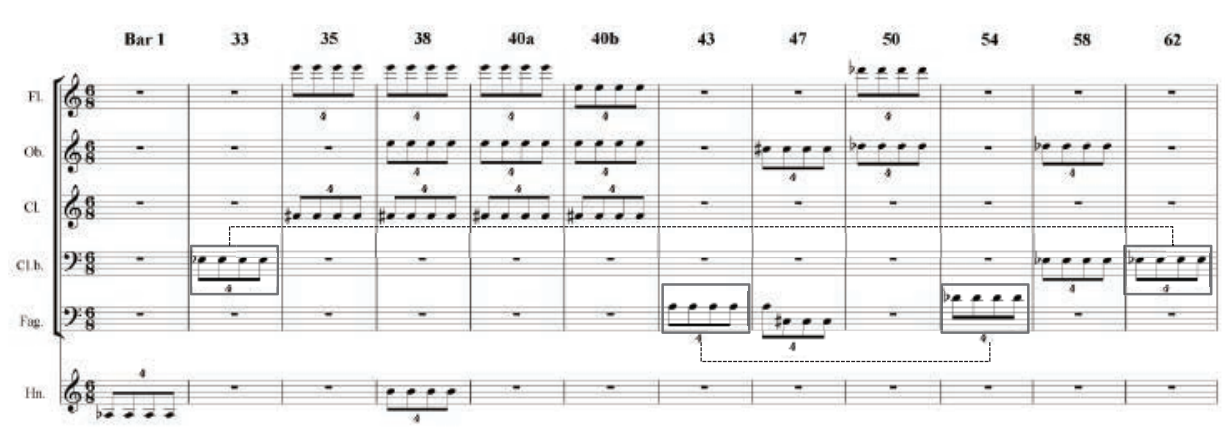

Ex. 13 Mládí, IV. movement: listing of all appearances of the repetitions-motif.

The fact that Janáček achieves the maximum of the limited Instrumentarium (six monophonic instruments), is remarkable. From the total of twelve combina- 
tions, ten differ from each other (bar 33 correlates with bar 62: Cl. b. / bar 43 with bar 54: Fag).

L. Janáček tries through many repetitions of a motif to achieve the maximum of the available instrumentarium. The result is a large variety of sound. His instrumental music is not only rich on basic tone colors, but also full with varied and partly closely related tone color nuances.

Charris Efthimiou completes Master in Composition with Beat Furrer and G. F. Haas in Graz. Ph.D. about Mozarts Symphonies with Prof. Dr. Peter Revers in Graz. Since 2010 is working as a Senior lecturer at the Music University of Graz.

\begin{abstract}
:
Leoš Janáček's orchestral and chamber music works belong to the most significant compositions of the first half of the 20th century. Besides his numerous stage works Janáček created a series of orchestral works, such as Taras Bulba (1915-18), Balada Blanická (1919) and Sinfonietta (1926). Due to their expressiveness, complexity and numerous instrumentational refinements they belong to the most exciting orchestral works of the interwar period. While a whole set of musicological treatises deal with formal, thematic and motivic aspects of his orchestral music, the finesses in instrumentation of his orchestral oeuvre remained largely unexplored. The aim of this paper is to look at the design of the bass and melody line in Janáček's Sinfonietta from a music-analytical perspective. The following aspects are presented in details: instrumentation of the bass line, octave doublings of the melody line within a movement, as well as the participation of the low strings and the brass section in the performance of the melody.
\end{abstract}

\title{
Key words:
}

instrumentation, Mládí, Sinfonietta, melody line, music analysis

\section{Bibliography:}

HOLLANDER, Hans. The Music of Leoš Janáček, It's Origin in Folklore. The Musical Quarterly, 1955, vol. 41, no. 2 (April), p. 171-176.

HONOLKA, Kurt. Leoš Janáček, Sein Leben, Sein Werk, Seine Zeit. Stuttgart: Belser Verlag, 1982.

KADERAVEK, Milan Robert. Stylistic Aspects of the Late Chamber Music of Leoš Janáček: an Analytic Study. Illinois: UMI Dissertation Services, 1971.

MACKERRAS, Charles. Orchestration problems and the revised edition. In: Leoš Janáček: Kát'a Kabanová, (ed. John Tyrell). Cambridge: Cambridge University Press, 1982, p. 143-154.

MAEHDER, Jürgen. Klangfarbe und Orchestertechnik im Spätwerk Leoš Janáčeks. In Leoš Janáček: Konzeption und Rezeption seines musikdramatischen Schaffens, (ed. Walter Bernhart). Anif / Salzburg: Verlag Müller-Speiser 1997, p. 67-85.

SCHNEBEL, Dieter. Das Späte Neue, Versuch über Janáčeks Werke 1918-1928. In Musik-Konzepte 7, Leoš Janáček (eds. Heinz-Klaus Metzger and Rainer Riehm). München: Johannesdruck Hans Pribil KG, 1979. 
